\title{
Analisis Regresi Logistik Biner pada Kejadian Transient Ischemic Attack (Tia) di RSUD Dr. Soetomo Surabaya
}

\author{
Adelia Rahma Fadhilah, Hari Basuki Notobroto \\ Departemen Biostatistika dan Kependudukan FKM Unair \\ Jl. Mulyorejo Kampus C Unair Surabaya 60115 \\ Alamat korespondensi: \\ Adelia Rahma Fadhilah, E-mail: della.adeliarahma@yahoo.com
}

\begin{abstract}
Analysis of the influence of risk factors aims to describe the unidirectional relationship between risk factors to an incident or a spesific disease, one of which is binary logistic regression. This analysis is applied to case of TIA because TIA is a warning that stroke will occur. This study was carried out to determine risk factors that affect case of TIA in Dr. Soetomo Regional Public Hospital Surabaya in 2012-2015 and the best binary logistic regression model. This study was an observational and case control study. Subjects were 90 inpatients at nerve division. Data were collected by observing the patient's card status to get information of variables examined. Independent variables were hypertension, dyslipidemia, and diabetes mellitus. Result of simultaneous test showed that at least one variable that affected TIA $(p=0,000)$. Partial test showed that hypertension $(p=0.015 ; O R=4.327)$, dyslipidemia $(p=0.000 ;$ OR $=10.455)$, and diabetes mellitus $(p=0.032 ;$ OR $=3.942)$ affected TIA $(p<0.05)$. This independent variables have contributed as much as 49\% to TIA with prediction accuracy was $67 \%$. Model obtained was fit $(p>0.05)$. Binary logistic regression can be used to analyze risk factors of TIA in Dr. Soetomo Regional Public Hospital Surabaya in 2012-2015 with high prediction accuracy. Patients with dyslipidemia have the highest risk of TIA. Hypertension or diabetes mellitus was also significant risk factor of TIA.
\end{abstract}

Keywords: binary logistic regression, TIA, risk factors

\begin{abstract}
ABSTRAK
Analisis pengaruh faktor risiko bertujuan untuk menggambarkan hubungan searah antara sekumpulan faktor risiko terhadap suatu kejadian atau penyakit tertentu, salah satunya adalah analisis regresi logistik biner. Analisis diterapkan pada kejadian TIA karena TIA merupakan peringatan bahwa stroke akan terjadi. Penelitian ini dilakukan untuk mengetahui faktor risiko yang berpengaruh terhadap kasus TIA di RSUD Dr. Soetomo Surabaya pada tahun 2012 sampai 2015, serta menentukan model regresi logistik biner terbaik. Penelitian dilakukan secara observasional dan dengan rancangan case control. Subjek penelitian yang digunakan adalah 90 pasien rawat inap di Poli Saraf. Pengambilan data dilakukan hanya dengan mengamati kartu status pasien untuk mendapatkan informasi tentang variabel yang diteliti. Variabel independen penelitian adalah hipertensi, dislipidemia, dan diabetes melitus. Hasil uji signifikansi parameter serentak menunjukkan bahwa minimal terdapat satu variabel yang mempengaruhi kejadian TIA $(\mathrm{p}=0,000)$. Pengujian secara parsial menunjukkan bahwa variabel hipertensi $(\mathrm{p}=0,015 ; \mathrm{OR}=$ $4,327)$, dislipidemia $(p=0,000 ; O R=10,455)$, dan diabetes melitus $(p=0,032 ; O R=3,942)$ mempengaruhi kejadian TIA $(\mathrm{p}<0,05)$. Variabel independen tersebut mempunyai kontribusi $49 \%$ terhadap kejadian TIA dengan ketepatan prediksinya adalah $67 \%$. Model yang diperoleh telah sesuai $(\mathrm{p}>0,05)$. Kesimpulan yang dapat ditarik adalah regresi logistik biner dapat digunakan untuk menganalisis faktor risiko TIA di RSUD Dr. Soetomo Surabaya tahun 2012-2015 dengan ketepatan prediksi yang tinggi. Hasil analisis tersebut menunjukkan bahwa pasien dengan dislipidemia memiliki risiko terkena TIA paling tinggi. Variabel hipertensi maupun diabetes melitus juga merupakan faktor risiko TIA yang bermakna.
\end{abstract}

Kata kunci: regresi logistik biner, TIA, faktor risiko

\section{PENDAHULUAN}

Statistika mampu berperan sebagai suatu alat yang digunakan untuk deskripsi, komparasi, korelasi dan regresi (Usman dan Akbar, 2006).
Statistika yang berperan untuk regresi mempunyai peran khusus yaitu bukan hanya meramalkan pengaruh suatu data terhadap data yang lain tetapi juga untuk mengestimasi kecenderungan peristiwa yang akan terjadi (Purwoto, 2007). 
Analisis regresi merupakan analisis hubungan atau pengaruh antara variabel bebas (variabel independen) dengan variabel terikat (variabel dependen) dan dikelompokkan menjadi dua, yaitu regresi linier dan regresi non linier. Regresi non linier bertujuan untuk menganalisis data hasil penelitian yang berbentuk kualitatif, salah satunya adalah analisis regresi logistik biner.

Regresi logistik biner merupakan salah satu metode yang dapat digunakan untuk mencari hubungan antara variabel dependen yang bersifat dichotomous (berskala nominal atau ordinal dengan dua kategori) dengan satu atau lebih variabel independen yang bersifat kontinyu atau kategorik (Agresti, 1990). Regresi logistik biner terdiri dari beberapa tahapan. Tahap pertama adalah uji independensi yang bertujuan untuk mengetahui apakah di antara variabel-variabel yang akan diteliti memiliki hubungan atau tidak. Uji independensi dapat dilakukan dengan Uji Pearson Chi-Square.

Tahapan selanjutnya adalah metode Maximum Likelihood untuk menentukan parameter model regresi logistik, kemudian uji signifikansi parameter secara keseluruhan dan individual untuk mengetahui pengaruh dari variabel independen terhadap variabel dependen sebelum menentukan model regresi logistik. Model regresi logistik yang telah diperoleh diuji kecocokan model agar dapat memberikan kesimpulan yang tepat terhadap data hasil observasi. Uji kecocokan ini diperlukan untuk mengetahui apakah model regresi logistik biner tersebut sudah layak digunakan. Uji kecocokan model untuk regresi logistik terdapat beberapa macam, salah satunya adalah uji Hosmer dan Lemeshow dengan hasil model regresi logistik biner yang terbaik.

Statistika secara praktis merupakan penerapan dari statistika matematis terhadap berbagai bidang ilmu, misalnya penerapan statistika pada ilmu biomedis dan kesehatan yang disebut biostatistika (Kim and Dailey, 2008). Pada bidang kesehatan, analisis regresi logistik biner dimanfaatkan untuk meneliti adanya pengaruh beberapa faktor risiko terhadap kejadian suatu penyakit dan dapat dijadikan sebagai upaya preventif dan promotif. Keunggulan analisis regresi logistik biner tersebut dapat diterapkan pada kejadian Transient Ischemic Attack (TIA) sebab TIA merupakan keadaan medis yang darurat dan peringatan bahwa stroke akan terjadi pada sepertiga pasien yang telah mengalaminya.

Stroke menurut World Health Organization (WHO) (1988) dalam Junaidi (2011), adalah suatu sindrom klinis dengan gejala berupa gangguan fungsi otak secara fokal maupun global, yang dapat menimbulkan kematian atau kecacatan yang menetap lebih dari 24 jam, tanpa penyebab lain, kecuali gangguan vaskular. Stroke terjadi karena terhambatnya aliran darah ke otak karena perdarahan (stroke hemoragik) ataupun sumbatan (stroke iskemik) dengan gejala dan tanda sesuai bagian otak yang terkena, yang dapat sembuh sempurna, sembuh dengan cacat, atau kematian. Insiden pada stroke hemoragik intrakranial sebesar $15 \%$ yang terdiri dari intraserebral $10 \%$ dan subaraknoid 5\%, sedangkan sisanya $85 \%$ disebabkan oleh stroke iskemik yang terdiri dari serangan iskemik sepintas (Transient Ischemic Attack/TIA) sebesar 40\%, trombosis serebri $20 \%$, emboli serebri $20 \%$, dan penyebab lainnya, seperti vaskulitis otak dan hipoperfusi serebral, sebesar $5 \%$. TIA merupakan penyebab stroke terbesar jika dilihat dari jumlah insidennya.

Definisi TIA menurut Institut Nasional Gangguan Neurologi dan Stroke (1990), seperti yang dikutip dalam Ellis et al (2011), adalah kehilangan fungsi otak fokal atau mata dengan gejala yang berlangsung kurang dari 24 jam. Risiko stroke tertinggi adalah pada 48 jam pertama setelah TIA. Diagnosis yang akurat dapat dicapai dengan memperoleh riwayat serangan mendadak gejala negatif yang berasal dari wilayah vaskular pasien stroke iskemik disertai dengan pemeriksaan normal dan tidak adanya neuroimaging yang menjadi bukti infark.

Penelitian vaskular Oxford University telah mengukur risiko stroke pada penderita TIA, yaitu $8 \%$ pada tujuh hari, $11,5 \%$ pada satu bulan, dan $17,3 \%$ pada tiga bulan. Penelitian lain mengatakan bahwa 18,8\% TIA dapat berubah menjadi stroke dalam waktu 10 tahun dari diagnosis TIA awal.

Studi di Abergavenny menyatakan bahwa TIA terjadi pada sekitar 35 orang per 100.000 penduduk setiap tahunnya, serta berkaitan dengan risiko stroke yang sangat tinggi pada bulan pertama serangan dan sampai satu tahun setelahnya (Ellis, et al., 2011). Secara keseluruhan, insiden TIA berkisar antara 200.000 sampai 500.000 kasus per tahunnya. 
Maka dari itu, diperlukan pengendalian faktor risiko secara ketat agar jumlah kejadian TIA tersebut dapat berkurang. Faktor risiko dari TIA itu sendiri adalah hipertensi, dislipidemia, dan diabetes melitus. Hipertensi adalah suatu keadaan di mana seseorang mengalami peningkatan tekanan darah di atas normal. Nilai normal tekanan darah seseorang dengan ukuran tinggi badan, berat badan, tingkat aktivitas normal dan kesehatan secara umum adalah 120/80 mmHg (Sudoyo, 2009). Dikatakan hipertensi bila tekanan darah lebih besar dari 140/90 mmHg.

Dislipidemia adalah kelainan metabolisme lipid yang ditandai dengan peningkatan maupun penurunan fraksi lipid dalam plasma. Kelainan fraksi lipid yang paling utama adalah kenaikan kadar kolesterol total ( $\geq 200 \mathrm{mg} / \mathrm{dl})$, kolesterol Low Density Lipoprotein (LDL) ( $\geq 150 \mathrm{mg} /$ dl), kenaikan kadar trigliserida ( $\geq 200 \mathrm{mg} / \mathrm{dl}$ ), atau penurunan kadar High Density Lipoprotein (HDL) $(<35 \mathrm{mg} / \mathrm{dl})$.

Diabetes melitus menyebabkan kadar lemak darah meningkat karena konversi lemak tubuh yang terganggu. Dikatakan menderita diabetes melitus jika kadar gula darah $>200 \mathrm{mg} / \mathrm{dl}$ (Sudoyo, 2009).

Faktor-faktor tersebut akan dianalisis dengan menggunakan regresi logistik biner untuk mengetahui faktor risiko apa yang paling berpengaruh, berapa besar pengaruhnya, dan bagaimana model regresi terbaik. terhadap kejadian TIA di RSUD Dr. Soetomo Surabaya pada tahun 2012 sampai 2015.

\section{METODE PENELITIAN}

\section{Rancang Bangun Penelitian}

Penelitian ini merupakan penelitian observasional, yaitu penelitian yang hanya melakukan pengamatan atau observasi dan tidak memberikan perlakuan atau intervensi pada subjek yang diteliti (responden). Desain penelitian yang digunakan adalah desain case control (kasus kontrol), yaitu adalah desain yang menilai hubungan paparan dan penyakit dengan menentukan sekelompok orang dengan penyakit tertentu (kasus) dan sekelompok orang yang tidak mempunyai penyakit tersebut (kontrol) kemudian membandingkan frekuensi paparan pada kedua kelompok tersebut.

\section{Lokasi dan Waktu Penelitian}

Penelitian dilakukan di rekam medis rawat inap Poli Saraf RSUD Dr. Soetomo Surabaya pada tanggal 10 Mei sampai 16 Mei 2016.

\section{Populasi Penelitian}

Populasi dalam penelitian ini, baik kelompok kasus maupun kontrol, adalah semua pasien rawat inap di Poli Penyakit Saraf RSUD Dr. Soetomo pada tahun 2012 sampai 2015.

\section{Besar dan Cara Pengambilan Sampel}

Sampel kasus yang digunakan sebanyak 30 pasien rawat inap yang terkena TIA, sedangkan sampel kontrol dihitung dua kali dari besar sampel kasus, yaitu 60 pasien rawat inap yang tidak terkena TIA. Teknik pengambilan sampel dilakukan dengan mengacak nomor rekam medis pasien rawat inap tersebut.

\section{Variabel Penelitian}

Variabel yang diteliti dapat dilihat pada kerangka teori sebagai berikut.

\section{Cara Pengumpulan dan Analisis Data}

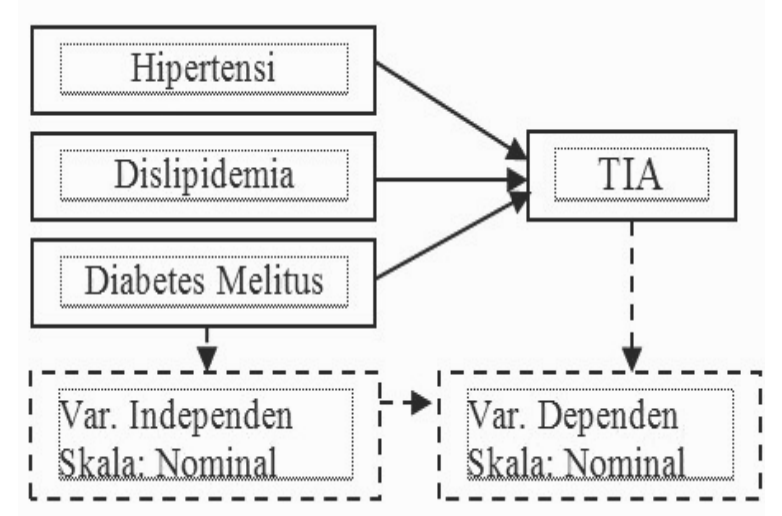

Gambar 1. Kerangka Teori.

Data dalam penelitian merupakan data sekunder yang diambil dari rekam medis dan kartu status pasien. Analisis data dilakukan secara deskriptif dan analitik. Analisis deskriptif bertujuan untuk memberikan gambaran variabel yang diteliti, sedangkan analisis analitik digunakan dalam pengolahan data dengan melakukan analisis terhadap sampel penelitian 
untuk mengetahui hubungan antar variabel dengan menggunakan uji statistik regresi logistik biner secara univariat dan multivariat.

\section{HASIL PENELITIAN}

Pasien yang melakukan rawat inap di Poli Saraf RSUD Dr. Soetomo Surabaya telah tercatat sesuai dengan kode ICD 2010. Kode ICD untuk penyakit saraf, yaitu kode G. Penelitian kali ini menggunakan kode ICD G 61 untuk populasi kontrol (tidak terkena TIA) dan kode ICD G 45 untuk populasi kasus (terkena TIA).

Tabel 1 menunjukkan bahwa pasien yang terkena TIA sebanyak 35 pasien $16,75 \%$ ) dari 209 pasien rawat inap pada tahun 2012 sampai 2015.

Tabel 1. Hasil Pemeriksaan Pasien Rawat Inap di Poli Saraf RSUD Dr. Soetomo Surabaya, 2012-2015

\begin{tabular}{lcc}
\hline \multicolumn{1}{c}{ Hasil Pemeriksaan } & Frekuensi & $\mathbf{\%}$ \\
\hline Tidak TIA (G 61) & 174 & 83,25 \\
TIA (G 45) & 35 & 16,75 \\
\hline Total & 209 & 100,00 \\
\hline
\end{tabular}

\section{Analisis Regresi Logistik Univariat}

Pasien yang tidak memiliki hipertensi sebagian besar tidak terkena TIA, yaitu sebanyak 47 pasien $(81,0 \%)$ dan pasien yang memiliki hipertensi sebagian besar terkena TIA, yaitu sebanyak 19 pasien $(59,4 \%)$. Hasil analisis univariatnya adalah $\mathrm{p}_{\text {value }}(0,000)<\alpha(0,05)$, artinya variabel hipertensi mempengaruhi kejadian TIA.

Tabel 2. Distribusi Pasien Berdasarkan Status Hipertensi Pasien terhadap Kejadian TIA, 2012-2015

\begin{tabular}{lcccccc}
\hline \multirow{2}{*}{ HT } & \multicolumn{3}{c}{ Hasil Pemeriksaan } & \multicolumn{2}{c}{ Total } \\
\cline { 2 - 5 } & \multicolumn{2}{c}{ Normal } & \multicolumn{2}{c}{ TIA } & \multirow{2}{*}{ N } & \% \\
\cline { 2 - 5 } & $\mathbf{f}$ & $\mathbf{\%}$ & $\mathbf{f}$ & $\mathbf{\%}$ & & \\
\hline Tidak & 47 & 81,0 & 11 & 19,0 & 58 & 100 \\
Ya & 13 & 40,6 & 19 & 59,4 & 32 & 100 \\
\hline Total & 60 & 66,7 & 30 & 33,3 & 90 & 100 \\
\hline
\end{tabular}

Tabel 3. Distribusi Pasien Berdasarkan Status Dislipidemia Pasien terhadap Kejadian TIA, 2012-2015

\begin{tabular}{lrrrrrr}
\hline \multirow{2}{*}{ DL } & \multicolumn{3}{c}{ Hasil Pemeriksaan } & \multicolumn{2}{c}{ Total } \\
\cline { 2 - 5 } & \multicolumn{2}{c}{ Normal } & \multicolumn{2}{c}{ TIA } & \multirow{2}{*}{ N } & \% \\
\cline { 2 - 5 } & $\mathbf{f}$ & $\mathbf{\%}$ & f & $\mathbf{\%}$ & & \\
\hline Tidak & 52 & 82,5 & 11 & 17,5 & 63 & 100 \\
Ya & 8 & 29,6 & 19 & 70,4 & 27 & 100 \\
\hline Total & 60 & 66,7 & 30 & 33,3 & 90 & 100 \\
\hline
\end{tabular}

Pasien yang dinyatakan tidak dislipidemia sebanyak 52 pasien $(82,5 \%)$ tidak terkena TIA dan 11 pasien $(17,5 \%)$ terkena TIA. Sebagian besar pasien yang terkena TIA memiliki dislipidemia, yaitu sebanyak 19 pasien dari 30 pasien. Hasil analisis univariatnya adalah $\mathrm{p}_{\text {value }}$ $(0,000)<\alpha(0,05)$, artinya variabel dislipidemia mempengaruhi kejadian TIA..

Tabel 4. Distribusi Pasien Berdasarkan Status Diabetes Melitus Pasien terhadap Kejadian TIA, 2012-2015

\begin{tabular}{lrrrrrr|}
\hline \multirow{2}{*}{ DM } & \multicolumn{3}{c}{ Hasil Pemeriksaan } & \multicolumn{2}{c|}{ Total } \\
\cline { 2 - 5 } & \multicolumn{2}{c}{ Normal } & \multicolumn{2}{c|}{ TIA } & \multirow{2}{*}{ N } & \% \\
\cline { 2 - 5 } & f & \% & f & \% & & \\
\hline Tidak & 51 & 78,5 & 14 & 21,5 & 65 & 100 \\
Ya & 9 & 36,0 & 16 & 64,0 & 25 & 100 \\
\hline Total & 60 & 66,7 & 30 & 33,3 & 90 & 100 \\
\hline
\end{tabular}

Jumlah pasien yang tidak memiliki diabetes melitus terkena TIA sebesar 21,5\% (14 pasien) dan tidak terkena TIA sebesar 78,5\% (51 pasien), sedangkan jumlah pasien yang memiliki diabetes melitus terkena TIA sebesar $64,0 \%$ dan tidak terkena TIA sebesar $36,0 \%$. Hasil analisis univariatnya adalah $\mathrm{p}_{\text {value }}(0,000)<\alpha(0,05)$, artinya variabel diabetes melitus mempengaruhi kejadian TIA.

\section{Analisis Regresi Logistik Multivariat}

Analisis multivariat dilakukan dengan memasukkan ketiga variabel independen (hipertensi, dislipidemia, dan diabetes melitus) dan didapatkan beberapa hasil. Hasil yang pertama adalah hasil uji independensi yang ditandai dengan $\mathrm{p}_{\text {value }}<\alpha(0,05)$. Parameter yang 
telah diestimasi akan diuji secara serentak dan parsial. Hasil uji secara serentak dapat dilihat pada tabel berikut.

Tabel 5. Omnibus Tests of Model Coefficients

\begin{tabular}{lccc}
\hline & Chi-square & df & Sig. \\
\hline Step 1 & 38,671 & 3 & 0,000 \\
Model 1 & 38,671 & 3 & 0,000 \\
\hline
\end{tabular}

Berdasarkan hasil likelihood $G$ ratio test pada tabel 5 dapat diketahui bahwa nilai $\mathrm{G}^{2}$ $(38,671)>\chi_{(0,05,3)}^{2}(17,730)$ atau nilai $\mathrm{p}_{\text {value }}$ $(0,000)<\alpha(0,05)$. Jika $\mathrm{p}_{\text {value }}<\alpha$, maka dilanjutkan dengan uji secara parsial yang dapat dilihat hasilnya pada tabel 6 .

Tabel 6 menunjukkan bahwa variabel hipertensi, dislipidemia, dan diabetes melitus memiliki nilai $\mathrm{p}_{\text {value }}$ kurang dari $\alpha(0,05)$. Variabel independen yang signifikan akan dimasukkan pada model regresi logistik. Model yang telah terbentuk akan diuji dengan uji kesesuaian model.

Tabel 6. Variables in the Equation

\begin{tabular}{lccc}
\hline \multicolumn{1}{c}{ Variabel } & B & Sig. & $\operatorname{Exp(B)}$ \\
\hline HT & 1,465 & 0,015 & 4,327 \\
Ya & & & \\
Tidak (ref) & & & \\
\hline DL & 2,347 & 0,000 & 10,455 \\
Ya & & & \\
Tidak (ref) & & & \\
\hline $\begin{array}{l}\text { DM } \\
\text { Ya }\end{array}$ & 1,372 & 0,032 & 3,942 \\
Tidak (ref) & & & \\
\hline
\end{tabular}

Hasil Hosmer and Lemeshow Test pada tabel 7 menunjukkan bahwa nilai signifikansi dari model sebesar 0,529 dengan tingkat kemaknaan sebesar $\alpha=0,05$ sehingga $\mathrm{p}_{\text {value }}$ $>\alpha$.

Tabel 7. Hosmer and Lemeshow Test

\begin{tabular}{cc}
\hline Chi-square & Sig. \\
\hline 3,174 & 0,529 \\
\hline
\end{tabular}

\section{PEMBAHASAN}

Populasi pada penelitian ini adalah semua pasien rawat inap di Poli Penyakit Saraf RSUD Dr. Soetomo pada tahun 2012 sampai 2015 yang dinyatakan secara medis terkena TIA dan tidak terkena TIA (normal). Sampel kasus penelitian ini adalah 30 pasien rawat inap yang dinyatakan terkena TIA dengan kode ICD G 45 karena keterbatasan jumlah kasus TIA di RSUD Dr. Soetomo Surabaya.

Sampel kontrolnya adalah 60 pasien rawat inap yang dinyatakan tidak terkena TIA maupun stroke dengan kode ICD G 61 (Guillain Barre Syndrome (GBS)) di setiap tahunnya yang dihitung dari jumlah dua kali sampel kasus. Data diperoleh dari rekam medis dan kartu status pasien rawat inap yang terpilih secara acak. Pengukuran pada subjek penelitian tidak melibatkan kontak langsung sehingga subjek tidak sadar bahwa mereka merupakan bagian dari penelitian dan tidak merasa terganggu selama proses penelitian, tetapi meninggalkan bukti dari perilaku sosial secara ilmiah (Kuntoro, 2009).

Kejadian TIA digambarkan dengan faktor risiko yang menjadi variabel pada penelitian ini. Variabel yang digunakan adalah hipertensi, dislipidemia, dan diabetes melitus. Indikator risiko tinggi pasien TIA meliputi tekanan darah lebih dari 140/90 $\mathrm{mmHg}$ dan riwayat diabetes (Anderson, et al., 2012). Subjek penelitian yang memiliki hipertensi dan mengalami TIA lebih besar daripada yang tidak memiliki hipertensi, yaitu $59,4 \%$. Penderita TIA juga dianggap memiliki obesitas dan memiliki serum kolesterol $\geq 220 \mathrm{mg} / \mathrm{dl}$ yang disebut hiperkolesterolemia/ dislipidemia (Sorgavi, et al., 2014).

Analisis pengaruh faktor risiko merupakan analisis yang digunakan untuk menggambarkan hubungan searah antara sekumpulan faktor risiko terhadap suatu kejadian atau penyakit tertentu. Analisis pengaruh faktor risiko yang sering banyak digunakan adalah analisis regresi logistik. Regresi logistik bertujuan untuk mengatasi kelemahan dari Linier Probability Model (LPM) yang dapat memberikan hasil kurang memuaskan karena menghasilkan taksiran probabilitas kurang dari nol atau lebih dari satu (Widiarta dan Wardana, 2011). 
Analisis regresi logistik terdiri dari dua macam, yaitu regresi logistik sederhana (bivariat) dan regresi logistik ganda (multivariat). Penelitian yang dilakukan oleh Erna Hayati tentang "Analisis Regresi Logistik untuk Mengetahui Faktor-Faktor yang Mempengaruhi Frekuensi Kedatangan Pelanggan di Pusat Perbelanjaan X" melakukan analisis regresi logistik sederhana sebelum analisis regresi logistik ganda. Analisis regresi logistik sederhana dilakukan agar dapat mengetahui pengaruh masing-masing variabel independen (faktor risiko) terhadap variabel dependen (kejadian TIA) secara individu sebelum dilakukan pemodelan secara bersama-sama.

Hasil regresi logistik sederhana pada penelitian ini menunjukkan bahwa ketiga variabel signifikan secara individu. Hasil tersebut berarti variabel hipertensi, dislipidemia, dan diabetes melitus mempengaruhi kejadian TIA di RSUD Dr. Soetomo Surabaya pada tahun 2012-2015. Variabel tersebut belum tentu signifikan pula apabila dimasukkan secara bersama-sama ke dalam analisis regresi logistik ganda. Analisis regresi logistik ganda memiliki beberapa tahapan untuk mendapatkan model regresi terbaik, yaitu uji independensi, estimasi parameter, uji signifikansi parameter, dan uji kesesuaian model.

\section{Uji Asumsi Klasik}

Uji normalitas tidak dilakukan karena model regresi logistik tidak memerlukan uji asumsi klasik tersebut, melainkan memerlukan uji independensi. Uji independensi untuk mendeteksi non multikolinieritas antar variabel independen. Non multikolinieritas merupakan asumsi regresi yang berarti bahwa antara peubah prediktor tidak terjadi hubungan sempurna maupun mendekati sempurna (Kurniasari, et al., 2008). Uji independensi dapat dilakukan dengan Uji Pearson Chi-Square. Hasil uji pearson chi-square menunjukkan bahwa terdapat multikolinieritas antara variabel hipertensi, dislipidemia, dan diabetes melitus. Variabel tersebut tetap dimasukkan dalam model karena diduga mempengaruhi kejadian TIA.

Hasil penelitian tersebut berkaitan juga dengan penelitian yang dilakukan oleh Virgiana Nanda Sari tentang "Pemilihan Model Regresi Logistik Multinomial dan Ordinal Terbaik".
Penelitian ini menyimpulkan bahwa variabel umur dan tingkat pengetahuan tidak dihilangkan dari model meskipun memiliki multikolinieritas. Hal ini dikarenakan kedua variabel tersebut diduga mempengaruhi tingkat tekanan darah, serta diperkuat dengan sifat nonmultikolinieritas antar variabel independen lainnya.

\section{Uji Signifikansi Parameter}

Uji signifikansi parameter dibagi menjadi dua, yaitu secara serentak dan parsial. Pengujian signifikansi parameter secara serentak bertujuan untuk membandingkan nilai pengamatan respons dengan penduga nilai respons untuk model penuh dan intersep (Hosmer dan Lemeshow, 2000). Pengujian ini dilakukan dengan uji rasio likelihood dan melibatkan ketiga faktor risiko TIA. Uji rasio likelihood ini merupakan uji rasio kemungkinan maksimum yang digunakan untuk menguji peranan variabel independen di dalam model secara bersama-sama (Susilo, 2014).

Hasil uji signifikansi parameter secara serentak yang ditunjukkan pada tabel 5 , yaitu variabel hipertensi, dislipidemia, dan diabetes melitus mempengaruhi kejadian TIA secara bersama-sama. Hasil tersebut juga dapat menyimpulkan bahwa minimal terdapat satu faktor risiko yang berpengaruh signifikan terhadap kejadian TIA.

Koefisien determinasi regresei logistiknya adalah 0,485 , artinya kontribusi faktor risiko tersebut terhadap kejadian TIA adalah $49 \%$. Hal ini sesuai dengan penelitian yang dilakukan oleh Oktani Haloho et al. tentang "Penerapan Analisis Regresi Logistik pada Pemakaian Alat Kontrasepsi Wanita". Penelitian menunjukkan bahwa koefisien determinasi regresi logistik sebesar 0,553 sehingga dapat dikatakan kontribusi variabel bebas terhadap variabel terikat adalah $55 \%$.

Faktor risiko yang berpengaruh ditunjukkan pada hasil pengujian signifikansi parameter secara parsial. Uji tersebut menunjukkan apakah suatu variabel independen tersebut layak untuk masuk ke dalam model regresi atau tidak (Agresti, 1990). Uji signifikansi parameter secara parsial menggunakan uji Wald Chi-square (Hosmer dan Lemeshow, 2000), serta dengan metode backward wald. Metode backward wald adalah 
dengan memasukkan semua variabel independen kemudian mengeliminasi satu persatu variabel yang tidak signifikan hingga tersisa variabel independen yang signifikan (Widhiarso, 2010).

Uji Wald menghasilkan semua variabel independen yang signifikan (tabel 6). Ketepatan prediksi dalam penelitian ini sebesar $67 \%$ yang dapat dilihat pada Classification Table (output SPSS). Besarnya pengaruh ketiga variabel tersebut dilihat dari nilai Odd Ratio (OR) (Hosmer dan Lemeshow, 2000). Nilai OR ketiga variabel tersebut ditunjukkan oleh nilai Exp (B) pada tabel 6 .

Variabel hipertensi dengan nilai OR 4,327 menjelaskan bahwa pasien yang memiliki tekanan darah tinggi akan berisiko terkena TIA 4,327 kali lebih besar dibandingkan dengan pasien yang tidak memiliki hipertensi (tekanan darah normal). Hipertensi yang tidak terkontrol adalah salah satu faktor risiko terpenting untuk TIA dan dapat menyebabkan kerusakan pembuluh darah (Chest Heart \& Stroke Scotland, 2014).

Penelitian yang dilakukan oleh George Howard et al. menunjukkan bahwa kelompok TIA (kasus) terdiri dari responden yang sedikit lebih tua dengan prevalensi stroke sebelumnya dan hipertensi yang tinggi. Hal ini dibuktikan dengan persentase hipertensi pada kasus TIA sebesar $65 \%$ dibanding dengan persentase hipertensi pada kasus katerisasi jantung (49\%). Pasien TIA dengan hipertensi menjadi prediktor kuat untuk kejadian stroke berikutnya (Simmons, et al., 2012). Pengurangan tekanan darah tinggi sangat penting dalam mengurangi risiko stroke (Heart and Stroke Foundation, 2016).

Variabel dislipidemia merupakan variabel independen yang paling berpengaruh terhadap kejadian TIA di RSUD Dr. Soetomo Surabaya pada tahun 2012 hingga 2015. Hal tersebut dikarenakan variabel dislipidemia memiliki nilai OR paling tinggi diantara kedua variabel independen lainnya, yaitu 10,455 . Nilai tersebut berarti bahwa pasien yang memiliki dislipidemia berisiko terkena TIA 10,455 kali lebih besar daripada pasien yang tidak memiliki dislipidemia. Tingkat kolesterol atau trigliserida yang tinggi dapat berkontribusi dalam perkembangan aterosklerosis yang mengarah ke TIA dan stroke (Heart and Stroke Foundaton, 2016).

Sebuah penelitian besar kohort prospektif menunjukkan bahwa terdapat hubungan yang kuat antara kadar serum kolesterol dengan iskemik serebral. Penelitian lain menunjukkan bahwa semakin besar penurunan tingkat Low Density Lipoprotein Cholesterol (LDL-C) semakin besar pula penurunan risiko stroke iskemik setelah TIA karena dislipidemia merupakan faktor risiko stroke iskemik yang signifikan dengan OR 1,89 (Simmons, et al., 2012). Penelitian yang dilakukan oleh Gaia Sirimarco et al. juga menunjukkan bahwa prevalensi dislipidemia yang lebih tinggi ditemukan pada pasien TIA dengan lesi iskemik yang terdeteksi pada MRI.

Variabel berikutnya adalah variabel diabetes melitus dengan nilai OR 3,942, artinya pasien yang memiliki diabetes melitus berisiko terkena TIA 3,942 kali lebih besar dibandingkan dengan pasien yang tidak memiliki diabetes melitus. Besarnya risiko pasien dengan diabetes melitus ini sesuai dengan penelitian lain yang dilakukan oleh Vijaya Sorganvi et al. Penelitian tersebut menemukan hubungan yang signifikan antara diabetes dengan stroke iskemik dan besar risiko responden terkena stroke iskemik dengan diabetes adalah 3,542 kali daripada responden yang tidak memiliki diabetes. Stroke iskemik dan TIA dianggap satu kesatuan, jika tidak ada rekomendasi yang berbeda maka rekomendasi dapat berlaku untuk kedua kondisi tersebut (Ringleb, et al., 2011).

\section{Model Regresi Logistik}

Model regresi logistik biner terbaik yang diperoleh adalah sebagai berikut.

Persamaan tersebut menunjukkan bahwa nilai intersepnya adalah 2,531. Apabila semua variabel bernilai 0 , yaitu pada saat responden mempunyai hipertensi, dislipidemia, dan diabetes melitus, maka besar proporsi atau probabilitas terkena TIA sebesar 0,074 .

$f(\mathbf{z})=\frac{1}{1+e^{2,531-1,465(\text { hipertensi) }-2,347(\text { dislipidemia) }-1,372(\text { diabetes })}}$ 


\section{Uji Kesesuaian Model}

Regresi logistik biner akan membentuk variabel dependen yang merupakan kombinasi linier dari variabel independen. Nilai variabel dependen ini akan ditransformasikan menjadi probabilitas dengan fungsi logit (Widiarta dan Wardana, 2011). Fungsi logit dalam penelitian ini adalah model regresi logistik biner dengan memasukkan tiga variabel independen yang signifikan, yaitu variabel hipertensi, dislipidemia, dan diabetes melitus.

Model regresi logistik biner tersebut diuji dengan menggunakan Hosmer and Lemeshow Test. Jika nilai statistik dari uji tersebut kurang dari dan sama dengan nilai kritis chi-square, maka keputusannya adalah model yang digunakan telah sesuai (Hosmer dan Lemeshow, 2000). Hasil dari uji Goodness of Fit Statistic yang ditunjukkan pada tabel 5.12 adalah nilai yang diamati maupun yang diprediksi tidak memiliki perbedaan yang bermakna. Hal ini menunjukkan bahwa model regresi logistik biner yang diperoleh dalam penelitian ini mampu memprediksi nilai observasinya (model is fit) (Haloho, et al., 2013).

\section{SIMPULAN DAN SARAN}

\section{Simpulan}

Hasil analisis yang telah dilakukan dapat disimpulkan bahwa analisis faktor risiko yang mempengaruhi kejadian TIA di RSUD Dr. Soetomo Surabaya tahun 2012-2015 dengan menggunakan metode regresi logistik biner menghasilkan variabel independen yang signifikan, yaitu variabel hipertensi, dislipidemia, dan diabetes melitus dengan kontribusi 49\%, serta ketepatan prediksi $67 \%$.

Faktor risiko yang paling berpengaruh terhadap TIA adalah dislipidemia dengan nilai OR sebesar 10,455, artinya pasien yang memiliki dislipidemia berisiko terkena TIA 10,455 kali lebih besar daripada pasien yang tidak memiliki dislipidemia. Model regresi logistik biner terbaik yang mampu memprediksi nilai observasinya, yaitu:

$f(\mathbf{Z})=\frac{1}{1+e^{2,531-1,465(\text { hipertensi) }-2,347(\text { dislipidemia })-1,372(\text { diabetes })}}$

\section{Saran}

Berdasarkan kesimpulan, peneliti dapat memberikan beberapa saran, yaitu RSUD Dr. Soetomo Surabaya dapat menjalin kerja sama dengan ahli statistik untuk menganalisis kasuskasus lainnya karena metode regresi logistik biner terbukti mampu menganalisis faktor risiko kejadian TIA di RSUD Dr. Soetomo Surabaya dan RSUD Dr. Soetomo dapat menindaklanjuti faktor risiko TIA ini sebagai upaya preventif dan promotif agar masyarakat lebih peka dan waspada terhadap TIA, serta penelitian berikutnya sebaiknya dapat menganalisis kasus TIA lebih dalam lagi dengan metode statistik lain karena kasus ini termasuk kasus yang sangat jarang terdeteksi di Indonesia sehingga kasus ini dapat diketahui banyak orang dan dapat dicegah sesegera mungkin.

\section{DAFTAR PUSTAKA}

Agresti, A. 1990. Categorical Data Analysis. New York: John Wiley and Sons, Inc.

Anderson, D. et al. 2012. Health Care Guideline: Diagnosis and Initial Treatment of Ischemic Stroke. 10th ed. Bloomington: Institute for Clinical Systems Improvement.

Chest Heart and Stroke Scotland. 2014. Understanding Transient Ischemic Attack (T.I.A.) and Minor Stroke. Scotland: Office of the Scottish Charity Regulator.

Ellis, H., Ahmed, T., dan Khanna, P. 2011. Life After Stroke and Transient Ischemic Attack. Abergavenny, Gerimed: 413-416.

Fitrianty, A., Delbra, Wardhani, N.W.S., dan Soehono, L.A. 2013. Ketepatan Klasifikasi dengan Analisis Regresi Logistik dan Multivariate Regression Splines (MARS) pada Data dengan Peubah Respons Biner. Malang: Jurusan Matematika Fakultas MIPA. Universitas Brawijaya.

Haloho, O., Sembiring, P., dan Manurung, A. 2013. Penerapan Analisis Regresi Logistik pada Pemakaian Alat Kontrasepsi Wanita. Jurnal Universitas Sumatera Utara, 1(1): pp. 51-61.

Hayati, E., 2002. Analisis Regresi Logistik untuk Mengetahui Faktor-Faktor yang Mempengaruhi Frekuensi Kedatangan Pelanggan di Pusat Perbelanjaan " $X$ ”. 
Lamongan: Fakultas Ekonomi. Universitas Islam Lamongan.

Heart and Stroke Foundation. 2016. Understanding Transient Ischemic Attack (TIA). Canada. CAT17810323.

Hosmer, D.W. dan Lemeshow, S. 2000. Applied Logistic Regression, John Wiley and Sons, New York.

Howard, G. et al. 1994. A Prospective Reevaluation of Transient Ischemic Attacks As a Risk Factor for Death and Fatal or Nonfatal Cardiovascular Events, Stroke, 25: 342-345. Tersedia di: < http://stroke.ahajourmas.org/ content/25/2/342> [diakses tanggal $12 \mathrm{Mei}$ 2016].

Indra, R. 2009. Faktor-faktor yang Memengaruhi Risiko Penyebab Penderita Kanker Payudara dengan Menggunakan Pendekatan Regresi Logistik. Surabaya: Jurusan Statistika Fakultas MIPA. Institut Teknologi Sepuluh November.

Junaidi, I. 2011. Stroke Waspadai Ancamannya. Yogyakarta: Penerbit Andi.

Kim, J.S., and Dailey, R.J. 2008. Biostatistic for Oral Healthcare. USA: Blackwell Munksgaard.

Kuntoro. 2009. Dasar Filosofis Metodologi Penelitian. Surabaya: Pustaka Melati.

Kurniasari, L., Sumarminingsih, E., dan Solimun. 2015. Permodelan Regresi Logistik dan Regresi Probit pada Peubah Respon Multinomial. Malang: Jurusan Matematika Fakultas MIPA. Universitas Brawijaya.

Pendlebury, S.T., Giles, M.F., dan Rothwell, P.M., Cambridge University Press. 2008. Epidemiology, Risk Factors, Pathophysiology and Causes of Transient Ischemic Attacks and Stroke. 978-0-521-73512-4.

Purwoto, A. 2007. Panduan Laboratorium Statistik Inferensial. Jakarta: Grasindo

Ringleb, P.A. et al., 2011. Chapter 9: Ischaemic Stroke and Transient Ischaemic Attack. European Handbook of Neurological Management, 1(2): 101-158.

Sari, V.N., Sumarminingsih, E., dan Bernadetha, M. 2010. Pemilihan Model Regresi Logistik Multinomial dan Ordinal Terbaik berdasarkan $R^{2} M C$. Fadden. Malang: Jurusan Matematika Fakultas MIPA. Universitas Brawijaya.
Siket, M.S., Ediow, J. 2013. Transient Ischemic Attack: An Evidence-Based Update. Emergency Medicine Practice, 15(1).

Simmons, B.B., Cirignano, B., dan Gadegbeku, A.B. 2012. Transient Ischemic Attack: Part I. Diagnosis and Evaluation. American Family Physician, 86(6): 521-526.

Simmons, B.B., Cirignano, B., dan Gadegbeku, A.B. 2012. Transient Ischemic Attack: Part II. Risk Factor Modification and Treatment. American Family Physician, 86(6): 527-532.

Sinaga, M., Sengkey, L., Angliadi, E. 2014. Gambaran Fungsi Kognitif pada Pasien Stroke Non Hemoragik Menggunakan Mini-Mental State Examination (MMSE). e-Clinic, 2(2).

Sirimarco, G. et al. 2011. Atherogenic Dyslipidemia in Patients With Transient Ischemic Attack. Stroke, 42: 2131-2137. Tersedia di: <http://stroke. ahajourmas. org/content/supp1/2011/07/07/ STROKEAHA.110.609727.DCO.html> [diakses tanggal 24 Mei 2016].

Sorganvi, V., Kulkarni, M.S., Udgiri, R., Kadeli, D., Atharga, S. 2014. Risk Factors For Ischemic Stroke-A Case Control Study. International Journal of Advanced Biological Research, 4(1): 9-12.

Sudoyo, A.W. dkk. 2009. Buku Ajar Ilmu Penyakit Dalam. Edisi V, Jilid III. Jakarta: Pusat Penerbitan Ilmu Penyakit Dalam.

Susilo, E., Islamiyati, A., AF., Muh. Saleh. 2014. Model Regresi Logistik Biner dengan Metode Penalized Maximum Likelihood.

Usman, H., Akbar, R.P.S. 2006. Pengantar Statistika. Edisi 2. Jakarta: PT. Bumi Aksara.

Utomo, S. 2009. Model Regresi Logistik untuk Menunjukkan Pengaruh Pendapatan per Kapita, Tingkat Pendidikan, dan Status Pekerjaan terhadap Status Gizi Masyarakat Kota Surakarta. Skripsi. Universitas Sebelas Maret.

Widhiarso, W. 2010. Berkenalan dengan MetodeMetode Analisis Regresi melalui SPSS. Yogyakarta: Fakultas Psikologi UGM.

Widiarta, I.B.P., Wardana, I.G.N. 2011. Analisis Pemilihan Moda dengan Regresi Logistik pada Rencana Koridor Trayek Trans Sarbagita. Jurnal Ilmiah Teknik Sipil, 15(2). 